\title{
Fibrin glue pleurodesis for pneumothorax in extremely preterm infants: a case report and literature review
}

\author{
Livia Drovandi ${ }^{1}$, Ilaria Cianchi ${ }^{1}$, Simone Pratesi ${ }^{1}$ and Carlo Dani ${ }^{1,2^{*}}$
}

\begin{abstract}
Background: Chest tube drainage and mechanical ventilation are effective treatment of symptomatic pneumothorax (PTX), but the best management of persistent ( $>7$ days) PTX is unknown.

Case presentation: We reported a case of successful fibrin glue pleurodesis of persistent PTX in an extremely preterm infant without adverse effects. We discussed previous literature on this treatment.

Conclusions: Overall, the twelve reported cases suggest that persistent PTX sealing with fibrin glue can represent a simple, quick, and effective treatment whose possible reported adverse effects are transient and do not cause permanent sequelae. Thus, fibrin glue pleurodesis might be considered a suitable therapeutic tool in very preterm infant with persistent PTX.
\end{abstract}

Keywords: Pneumothorax, Fibrin glue, Preterm infant

\section{Background}

Pneumothorax (PTX) is one of the major complications in extremely preterm infants with respiratory failure and is associated to high mortality and morbidity $[1,2]$. After the introduction of surfactant replacement therapy, its incidence is dropped and now is around $1-2 \%[1,2]$. Asymptomatic PTX without underlying pulmonary disease does not require any treatment, but in case of symptomatic PTX insertion of a chest tube and air drainage are required [1]. Although necessary, chest tube placement can lead to several complications in neonates, such as lung injuries, insertion site and pulmonary infections, phrenic nerve paralysis, chylothorax, and hemorrhagic pericardial effusion [1]. Usually chest tube drainage, positioning with the affected side down, low lung volume strategy, and high frequency oscillatory ventilation are effective treatment of PTX and allow its recovery in few days but, sometimes, mainly in patients with large bronchopleural fistulas, it can persist for several days [2].

\footnotetext{
* Correspondence: cdani@unifi.it

${ }^{1}$ Division of Neonatology, Careggi University Hospital of Florence, Largo Brambilla 3, 50141 Florence, Italy

${ }^{2}$ Department of Neurosciences, Psychology, Drug Research and Child Health, Careggi University Hospital of Florence, Florence, Italy
}

Bhatia and Mathew proposed that PTX longer than 7 days should be defined as persistent PTX [3]. They demonstrated that preterm infants with persistent PTX have higher risk of developing chronic lung disease than infants in whom PTX resolved before [3].

Unfortunately, there are not guidelines indicating the most appropriate approach to persistent PTX before considering more invasive procedures, such as pleurectomy, chemical pleurodesis, and selective intubation of the contralateral bronchus [4]. On the other hand, the risk of associated morbidities, such as intracranial hemorrhage, acute hypotension, air embolus and circulatory failure, urges the treatment of persistent PTX [2].

Fibrin glue is a two-component material consisting of concentrated human fibrinogen and thrombin imitating the coagulation process of the body. By combining the thrombin and fibrinogen component conversion of fibrinogen to fibrin takes place and a clot is formed by a three-dimensional fibrin network [5]. Fibrin glue on-label indications in adults include hemostasis, colonic sealing, and skin graft attachment [6]. Recent clinical and experimental uses include tissue or mesh attachment, fistula closure, lymphatic sealing, adhesion prevention, drug delivery, and tissue engineering [6].

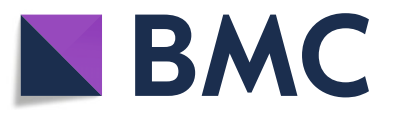

(c) The Author(s). 2018 Open Access This article is distributed under the terms of the Creative Commons Attribution 4.0 International License (http://creativecommons.org/licenses/by/4.0/), which permits unrestricted use, distribution, and reproduction in any medium, provided you give appropriate credit to the original author(s) and the source, provide a link to the Creative Commons license, and indicate if changes were made. The Creative Commons Public Domain Dedication waiver (http://creativecommons.org/publicdomain/zero/1.0/) applies to the data made available in this article, unless otherwise stated. 

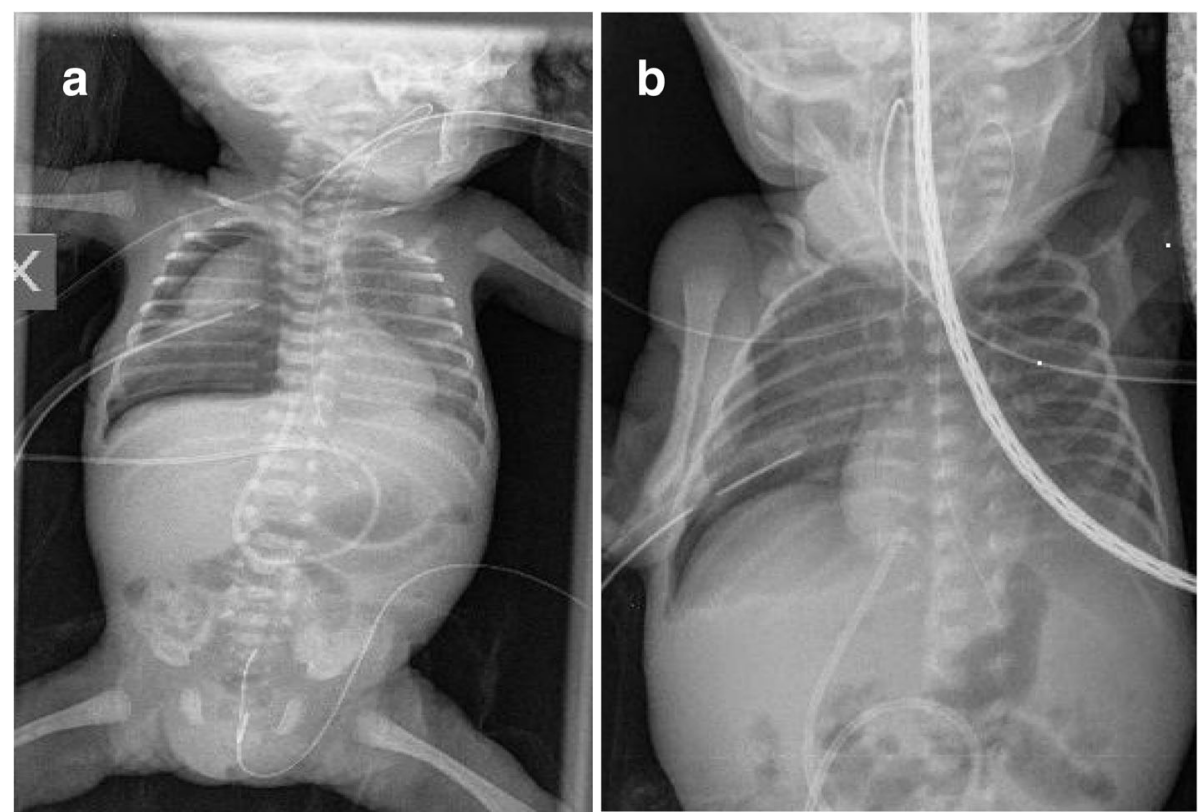

Fig. 1 PTX in the first and fourteenth day of life. Chest x-ray showing right-sided PTX in the first day of life (a) persisting in the fourteenth day of life (b)
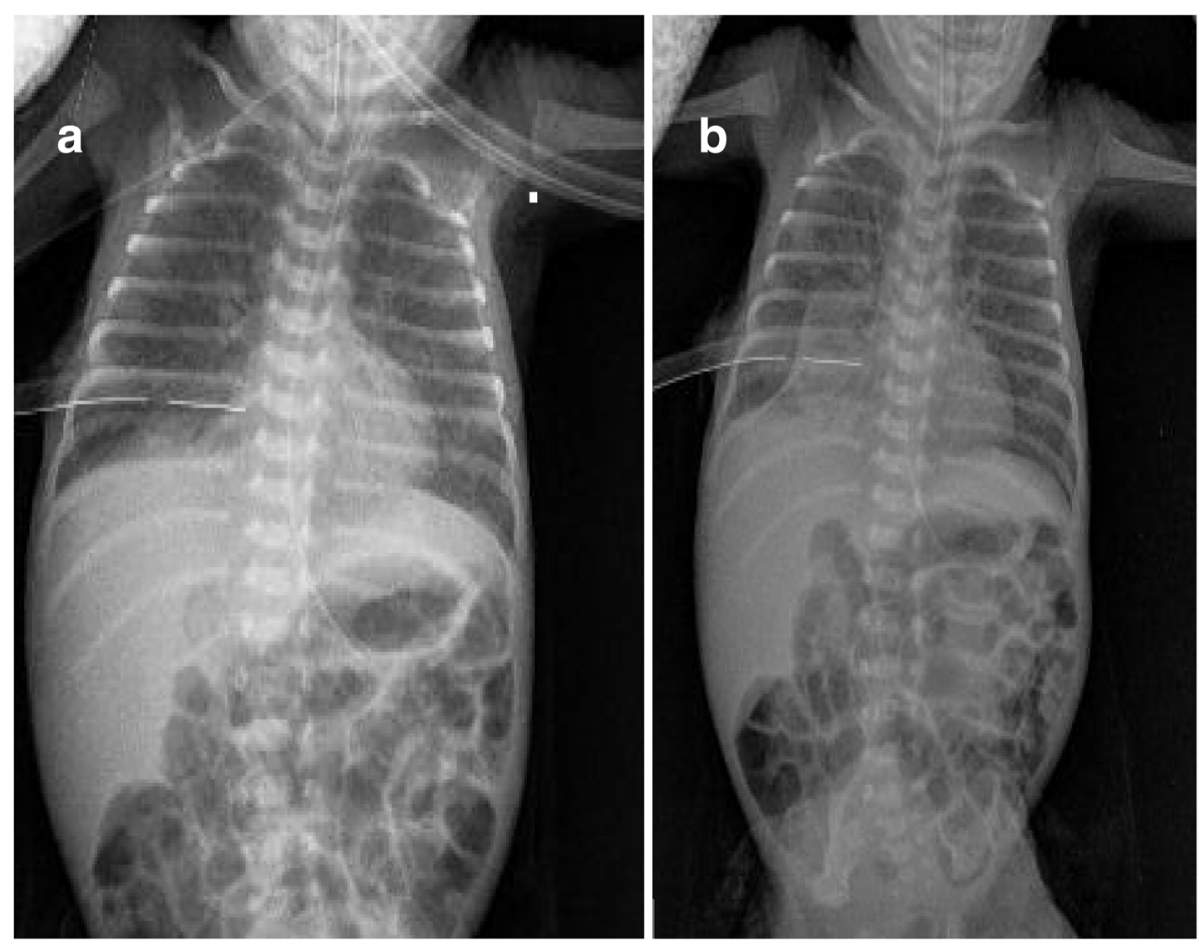

Fig. 2 Chest $x$-ray after fibrin glue injection. Chest x-ray at $30 \mathrm{~min}(\mathbf{a})$ and $12 \mathrm{~h}$ (b) after fibrin glue injection. A minimal PTX was appreciable in (a) and disappeared in (b). At the distal tip of the chest tube is visible a radiopaque area referable to the fibrin glue clot more evident in (b) than in (a) 
The first case of successful fibrin glue pleurodesis to seal a persistent PTX in a preterm infant has been reported in 1993 by Berger et al. [7]. From then, other case reports have been published [1, 2, 8, 9] suggesting that this procedure is effective in sealing persistent PTX in these patients without inducing severe adverse effects.

Thus, the purpose of this report is to document a further case of fibrin glue pleurodesis of persistent PTX in an extremely preterm infant, and to discuss previous literature on this issue for drawing the attention of Neonatologists to this little-known promising treatment.

\section{Case presentation}

A male was born at 26 weeks of gestation by cesarean section due to maternal vaginal bleeding after antenatal steroids. His birth weight was $810 \mathrm{~g}$ and Apgar scores were 7 at $1 \mathrm{~min}$ and 8 at $5 \mathrm{~min}$. Non-invasive mechanical ventilation (N-IMV with the following parameters: peak inspiratory pressure $18 \mathrm{~cm} \mathrm{H}_{2} \mathrm{O}$, respiratory rate $60 / \mathrm{min}$, positive end expiratory pressure $5 \mathrm{~cm} \mathrm{H}_{2} \mathrm{O}, \mathrm{FiO}_{2} 0.35$ ) was started immediately after delivery because of respiratory distress and continued in neonatal intensive care unit (NICU). Our patient was treated with surfactant $(200 \mathrm{mg} / \mathrm{kg}$ of Curosurf, Chiesi Farmaceutici Spa, Parma, Italy) with the InSURE (Intubation-SURfactant-Extubation) procedure at $2 \mathrm{~h}$ of life when $\mathrm{FiO}_{2}$ was 0.40 . At $24 \mathrm{~h}$ of life a second dose of surfactant $(100 \mathrm{mg} / \mathrm{kg})$ was given (again with the InSURE procedure) for the worsening of respiratory failure $\left(\mathrm{FiO}_{2}\right.$ 0.45), but immediately after the procedure he developed a right-sided PTX (Fig. 1). Therefore, high frequency oscillatory ventilation (HFOV) was started and chest tube was placed on $10 \mathrm{~cm} \mathrm{H}_{2} \mathrm{O}$ suction for continuous pleural drainage. On the fourteenth day of life the PTX persisted (Fig. 1) and, obtained informed parental consent, we performed chest pleurodesis with fibrin glue.

The homologous fibrin glue (Tisseel ${ }^{\circledR}$, Baxter, Lurago d'Erba, Italy) was prepared in a prefilled double chamber syringe which contains sealer protein solution (with synthetic aprotinin) in one chamber and thrombin solution (with calcium chloride) in the other chamber resulting in $10 \mathrm{ml}$ of product ready for use. The administration procedure was similar to previous reports [1, 2, 7-9]: a 5-Fr umbilical catheter was placed into the $10 \mathrm{~F}$ chest tube during HFOV and $5 \mathrm{~mL}$ of fibrin were slowly injected into the right pleural space. After the tube was completely pulled by the glue, the catheter was slowly extracted. During the 5 min injection heart rate was stable, and $\mathrm{SpO}_{2}$ was $>90 \%$ with unchanged $\mathrm{FiO}_{2}$. The procedure was followed by a quick and marked reduction in airflow through the chest tube and chest X-ray performed $30 \mathrm{~min}$ later showed a minimal right PTX (Fig. 2). After $12 \mathrm{~h}$, no air outflow was visible through the chest tube and PTX disappeared at chest X-ray (Fig. 2); 24 h later the tube was clamped and $48 \mathrm{~h}$ after the fibrin glue pleurodesis it was definitely removed. Five days later mechanical ventilation was stopped, and non-invasive ventilatory support was finally interrupted on 78 day of life when chest X-ray demonstrated the disappearance of fibrin glue clot (Fig. 3).

\section{Discussion}

The management of persistent PTX is not well established but prolonged chest tube placement and mechanical ventilation certainly increase the risk of developing severe complications (i.e.: infections, hemodynamic disturbances, bronchopulmonary dysplasia, etc.), especially in the subset of preterm infant population. Therefore, a relatively simple and quick procedure such as the fibrin glue pleurodesis may be very appealing for the treatment of persistent PTX.

Previous studies reported eleven cases of persistent PTX sealing with fibrin glue in very preterm infants [1, 2, 7-9] (Table 1). As in our case, fibrin glue pleurodesis was successful in all survived patients in whom PTX resolved within $48 \mathrm{~h}$ from the treatment as demonstrated by control chest x-rays [1, 2, 7-9]. The dose of fibrin glue varied from 3.5 [2] to $10 \mathrm{~mL}$ [7], in relationship to different

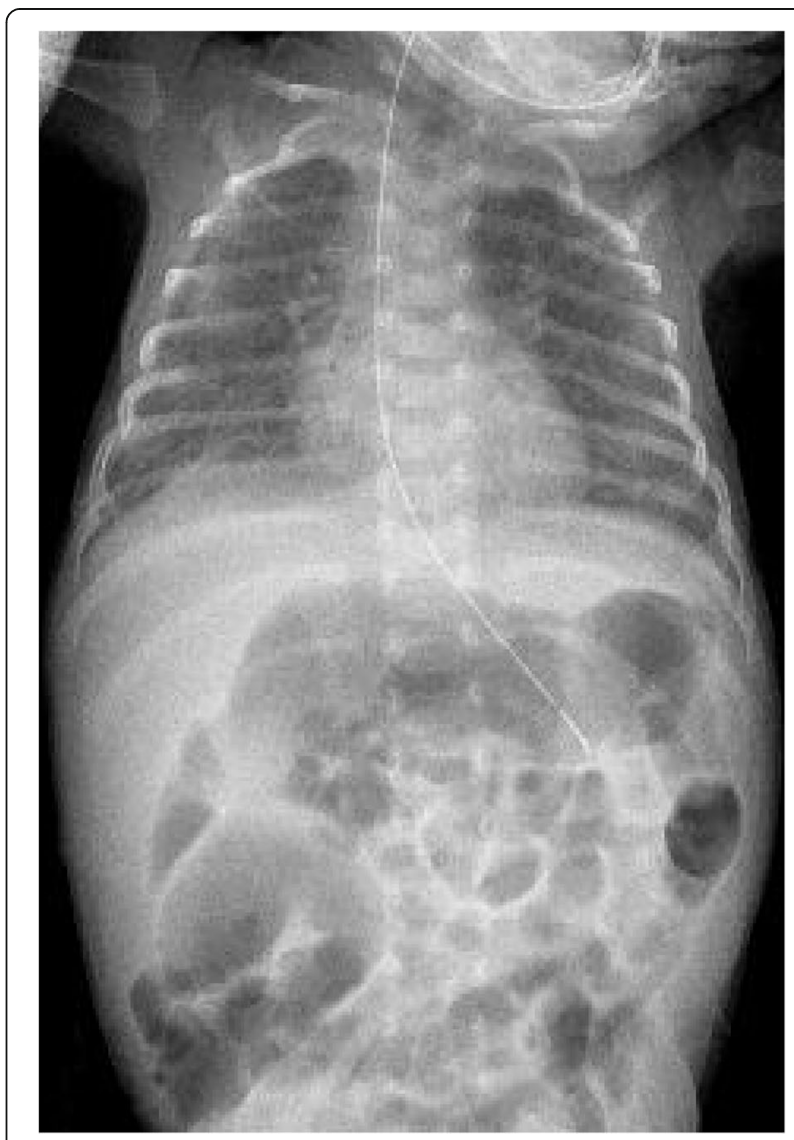

Fig. 3 Chest $x$-ray at discharge. Chest $x$-ray at 78 day of life showing the disappearance of the fibrin glue 
Table 1 Summary of reported cases of fibrin glue pleurodesis for persistent PTX in preterm infants

\begin{tabular}{lllllll}
\hline & Gestational age (wks) & Birth weight $(\mathrm{g})$ & Number of cases & Age at treatment (d) & Fibrin glue dose $(\mathrm{mL})$ & Complications \\
\hline Berger [7] & 26 & 850 & 1 & 30 & 10 & - \\
Kuint [9] & 31 & - & 1 & 59 & 5 & - \\
Sarkar [8] & $24-29$ & $530-1500$ & 7 & & & $\begin{array}{l}\text { Bradycardia, hypercalcemia, } \\
\text { skin necrosis, transient } \\
\text { diaphragm paralysis }\end{array}$ \\
& & & & & 3.5 & - \\
Campolat [2] & 25 & 790 & 1 & 15 & 6 & - \\
Nishizaki [1] & 25 & 764 & 1 & 8 & \\
\hline
\end{tabular}

types of fibrin glue and different injection devices. In the majority of cases a single course of fibrin glue was effective [1, 2, 7-9], but in two cases of recurrent PTX a second course was successfully performed [8]. Moreover, one patient had bilateral persistent PTX and received successful bilateral treatment [1]. Adverse effects were associated to the procedure in 5 patients in a single study [8], including bradycardia, hypercalcemia, skin necrosis, and diaphragmatic paralysis. It has been speculated that most of the complications (bradycardia, hypercalcemia, and the skin necrosis) were secondary to the concentration of calcium in the fibrin glue [8]. Nevertheless, these adverse effects did not occur in the remaining 7 patients (including ours) [1, 2, 7], and, in any case, they were transient and did not cause severe permanent sequelae [1, 2, 7-9]. However, the actual role of calcium is difficult to evaluate because different types of fibrin glue with different calcium content were used [1, 2, 7-9]. Possible effects of fibrin glue on patients' long-term pulmonary function might be a source of concern, However, our case and previous studies showed that chest X-rays performed at discharge [7], or later $[1,9]$ did not evidence lung abnormalities referable to fibrin glue pleurodesis.

Between possible treatments of persistent PTX, pleurectomy is too much invasive and, therefore, unfeasible in very preterm infants, while selective intubation of contralateral bronchus is very difficult particularly when the left main stem bronchus has to be selectively intubated. Pleurodesis with povidone-iodine has been reported in refractory chylotorax in newborns [10] and in a single-case of persistent PTX [4]. However, the use of povidone-iodine for pleurodesis can rise some concerns in very preterm infants due its chemical inflammatory effects, and the iodine oxidative and cytotoxic properties plus the risk of secondary hypothyroidisms [4, 10]. Moreover, the povidone-iodine pleurodesis in neonates has been associated with adverse effects, such as pain [11], lung or lobar collapse [11], and acute renal failure [12]. Conversely, fibrin glue is a human product that is catabolized by physiologic fibrinolytic agents whose reported adverse effects seem to be less severe.

\section{Conclusions}

The best management of persistent PTX in very preterm infants has not been reported in literature and the appropriate duration of standard therapy (pleural drainage through a chest tube during mechanical ventilation) before considering more invasive procedures has not been established. We reported a case of persistent PTX in an extremely low birth-weight infant who was successfully treated with fibrin glue pleurodesis. Our and previous case reports [1, 2, 7-9] suggest that persistent PTX sealing with fibrin glue can represent a simple, quick, and effective treatment whose possible reported adverse effects are transient and do not cause permanent sequelae. Thus, we believe that fibrin glue pleurodesis might be considered a suitable therapeutic tool in very preterm infant with persistent PTX.

\section{Abbreviations}

HFOV: High frequency oscillatory ventilation; InSURE: Intubation-SURfactantExtubation; N-IMV: Non-invasive mechanical ventilation; PTX: Pneumothorax

\section{Funding}

We had no specific fund for this study.

Availability of data and materials

Data sharing is not applicable to this article as no datasets were generated or analysed during the current study.

\section{Authors' contributions}

LV wrote the first draft of the paper. CD conceived the study and wrote the final manuscript. SP and CP reviewed literature. All authors reviewed and approved the final manuscript.

Ethics approval and consent to participate

Not applicable.

Consent for publication

The present study was submitted after parents' informed consent approval.

Competing interests

The authors declare that they have no competing interests.

\section{Publisher's Note}

Springer Nature remains neutral with regard to jurisdictional claims in published maps and institutional affiliations. 
Received: 13 April 2018 Accepted: 6 August 2018

Published online: 14 August 2018

\section{References}

1. Nishizaki N, Suganuma H, Nagata S, Shimizu T. Use of fibrin glue in the treatment of pneumothorax in premature infant. Pediatr Int. 2012;54:416-9.

2. Canpolat FE, Yurdakök M, Yurttutan S. Fibrin glue for persistent pneumothorax in an extremely low birth weight infant. Indian Pediatr. 2006; 43:646-7.

3. Bhatia J, Mathew OP. Resolution of pneumothorax in neonates. Crit Care Med. 1985;13:417-9.

4. Arayici S, Simsek GK, Oncel MY, Yilmaz Y, Canpolat FE, Dilmen U. Povidoneiodine for persistent air leak in an extremely low birth weight infant. J Pediatr Surg. 2013;48:E21-3.

5. Buchta C, Hedrich HC, Macher M, Höcker P, Redl H. Biochemical characterization of autologous fibrin sealants produced by $\mathrm{CryoSea}^{\bullet}$ and Vivostat ${ }^{\oplus}$ in comparison to the homologous fibrin sealant product Tissucol/ Tisseel $^{\ominus}$. Biomaterials. 2005;26:6233-41.

6. Spotnitz WD. Fibrin sealant: past, present, and future: a brief review. World J Surg. 2010;34:632-4

7. Berger JT, Gilhooly J. Fibrin glue treatment of persistent pneumothorax in a premature infant. J Pediatr. 1993;122:958-60

8. Sarkar S, Hussain N, Herson V. Fibrin glue for persistent pneumothorax in neonates. J Perinatol. 2003;23:82-4.

9. Kuint J, Lubin D, Martinowitz U, Linder N. Fibrin glue treatment for recurrent pneumothorax in a premature infant. Am J Perinatol. 1996;13:245-7.

10. Scottoni F, Fusaro F, Conforti A, Morini F, Bagolan P. Pleurodesis with povidone-iodine for refractory chylothorax in newborns: personal experience and literature review. J Pediatr Surg. 2015;50:1722-5.

11. Brissaud O, Desfrere L, Mohsen R, Fayon M, Demarquez JL. Congenital idiopathic chylothorax in neonates: chemical pleurodesis with povidoneiodine (betadine). Arch Dis Child Fetal Neonatal Ed. 2003;88:F531-3.

12. Mitanchez D, Walter-Nicolet E, Salomon R, Bavoux F, Hubert P. Congenital chylothorax: what is the best strategy? Arch Dis Child Fetal Neonatal Ed. 2006;91:F153-4.

Ready to submit your research? Choose BMC and benefit from:

- fast, convenient online submission

- thorough peer review by experienced researchers in your field

- rapid publication on acceptance

- support for research data, including large and complex data types

- gold Open Access which fosters wider collaboration and increased citations

- maximum visibility for your research: over $100 \mathrm{M}$ website views per year

At $\mathrm{BMC}$, research is always in progress.

Learn more biomedcentral.com/submissions 